\title{
Irritable bowel syndrome - psychiatric issues
}

\author{
Zespół jelita drażliwego - aspekty psychiatryczne \\ Joanna Niedziałek BDEF, Marta Pachla BDEF, Aleksandra Kordyga BDEF, \\ Łukasz Proć BDEF, Ewelina Soroka ADE, https://orcid.org/0000-0001-6909-2749, \\ Marcin Olajossy DE, https://orcid.org/0000-0002-1001-3185
}

II Department of Psychiatry and Psychiatric Rehabilitation, Medical University of Lublin

\begin{abstract}
Introduction: Irritable bowel syndrome is a chronic gastrointestinal disease classified as a functional gastrointestinal disorder. It has been diagnosed on the basis of the so-called Rome IV criteria since 2016. The prevalence of IBS in the general population is about $10-20 \%$, with most patients being women. The etiology of the syndrome is multifactorial and is associated with visceral sensory dysfunction, abnormalities of motor and secretory bowel function, a history of infectious diarrhea and abnormalities in gut microbiota, dysregulation of the brain-gut axis (the influence of the hypothalamic-pituitary-adrenal axis and sex hormones), genetic, psychosocial, and environmental factors, and the patient's personality traits. IBS patients may show differences in the structure and function of the brain when compared to healthy control individuals. Treatment of IBS involves the use of non-pharmacological interventions (psychotherapy, education, hypnotherapy, dietary modifications, regular physical activity) and pharmacotherapy (cholinolytic drugs, opioid receptor antagonists, tricyclic antidepressants, serotonin 5-HT3 receptor antagonists and 5-HT4 agonists).

Aim: The aim of the authors of this work is to draw attention to certain psychiatric aspects of the irritable bowel syndrome. It meets the criteria for a somatization disorder. Somatization is an important psychological factor directly related to the severity of IBS. It is estimated that the prevalence of psychiatric disorders among IBS patients ranges from $40 \%$ to $90 \%$ and is higher than in the general population. Affective disorders and anxiety disorders are the most commonly diagnosed.

Method: The article reviews the research and works available in the Google Scholar and PubMed databases combining the issue of IBS with psychiatric aspects, i.e. common for IBS and psychiatric disorders, etiopathogenesis, the concept of somatization in the context of IBS, and the coexistence of diseases and mental disorders with the irritable bowel syndrome.
\end{abstract}

Conclusion: Further research is needed to determine the causes of comorbidity of IBS and mental disorders.

Keywords: irritable bowel syndrome, somatization, mental illness

\section{Streszczenie}

Wstęp: Zespół jelita drażliwego jest przewlekłą chorobą przewodu pokarmowego zaliczaną do czynnościowych zaburzeń żołądkowo-jelitowych, a jego rozpoznanie ustalane jest w oparciu o tzw. Kryteria Rzymskie IV z 2016 roku. Częstość występowania IBS w populacji ogólnej wynosi ok. 10-20\%, z większym rozpowszechnieniem wśród kobiet.

W etiologii zespołu jelita drażliwego uwzględnia się: zaburzenia czucia trzewnego, czynności motorycznej i wydzielniczej jelit, przebycie biegunki infekcyjnej i zaburzenia mikroflory, dysregulację osi mózg-jelito (wpływ osi podwzgórze-przysadkanadnercza oraz hormonów płciowych), czynniki genetyczne, psychospołeczne, środowiskowe oraz cechy osobowości pacjentów. Leczenie IBS obejmuje stosowanie metod niefarmakologicznych (psychoterapia, edukacja, hipnoterapia, modyfikacje dietetyczne, regularna aktywność fizyczna) oraz farmakoterapii (leki cholinolityczne, antagoniści receptora opioidowego, trójcykliczne leki przeciwdepresyjne, antagoniści receptorów serotoninowych 5-HT3 oraz agoniści 5-HT4).

Cel: Celem autorów niniejszej pracy jest zwrócenie uwagi na pewne aspekty psychiatryczne zespołu jelita drażliwego. Spełnia on bowiem kryteria zaburzenia somatyzacyjnego. Somatyzacja jest istotnym czynnikiem psychologicznym bezpośrednio związanym z nasileniem IBS. Szacuje się, że współczynnik rozpowszechnienia zaburzeń psychicznych wśród chorych na IBS waha się od 40\% do 90\% i jest większy niż w populacji ogólnej. 
Z IBS najczęściej współwystępują zaburzenia afektywne i zaburzenia lękowe.

Metoda: W artykule dokonano przeglądu, dostępnych w bazach Google Scholar i PubMed, badań i prac łączących zagadnienie, jakim jest IBS $\mathrm{z}$ aspektami psychiatrycznymi tj. wspólną dla IBS i zaburzeń psychicznych etiopatogenezę, pojęcia somatyzacji w kontekście IBS

$* * *$

In recent years, researchers and medical practitioners have shown increased interest in the relationship between the pathophysiology of the digestive tract and the brain. The 'brain-gut" axis has been studied from multiple perspectives.

Irritable bowel syndrome (IBS) is a chronic disease of the gastrointestinal tract belonging to the category of functional gastrointestinal disorders. Characteristic symptoms of IBS include chronic abdominal pain and changed bowel habits [1]. Some IBS patients, apart from gastrointestinal symptoms, also report nonintestinal somatic symptoms as well as mental symptoms (fatigability, sleep disturbances, loss of appetite, anxiety, etc.) [2]. The estimated prevalence of IBS in the general population is about $10-20 \%$, with the highest incidence being observed between the ages of 30 and 40 years. Women are approximately twice more likely to be affected than men, with some studies reporting a three or four times greater prevalence of IBS among women compared to men [3].

Irritable bowel syndrome is diagnosed after exclusion of the organic gastrointestinal disease. The diagnosis is based on the so-called Rome IV criteria from 2016 [4].

According to these diagnostic criteria, IBS can be diagnosed when the patient has had recurrent abdominal pain at least 1 day a week for the last 3 months. The first symptoms usually take place at least 6 months before diagnosis. This period allows the disease to be considered chronic. In order to be able to diagnose the disease as an IBS, the pain must also meet at least two of the following three criteria:

- is associated with defecation,

- is associated with a change in the frequency of bowel movements,

- is associated with a change in stool consistency [4].

The diagnosis of IBS is a diagnosis of exclusion of an organic disease.

Depending on the dominant symptoms, IBS can be divided into:

- IBS with constipation (IBS-C)

- IBS with diarrhea (IBS-D)

- Mixed IBS (IBS-M)

- Unsubtyped IBS (IBS-U) [1, 4]. oraz współwystępowanie chorób i zaburzeń psychicznych z zespołem jelita drażliwego.

Wnioski: Konieczne są dalsze badania określające przyczyny współwystępowania IBS i zaburzeń psychicznych.

Słowa kluczowe: zespół jelita drażliwego, somatyzacja, choroba psychiczna

Until now, the underlying causes of IBS are not fully understood. The etiology of IBS is being linked to multiple factors, mainly interactions between biological and psychosocial factors. Various theories regarding the pathophysiology of this syndrome have been put forward, which associate the disease with changes in the CNS, abnormalities of the hypothalamic-pituitaryadrenal axis, inflammation, postinfectious agents, abnormalities in gut microbiota, visceral hypersensitivity, genetic susceptibility, immune system dysfunctions, and psychosocial factors $[1,5]$.

This multifactorial pathogenesis entails the need for an interdisciplinary approach to the diagnosis and treatment of patients with IBS.

The present article reviews previous research into the associations of IBS with psychiatric conditions, in particular the common etiopathogenesis of IBS and certain mental disorders, the concept of somatization in IBS, and comorbidity of IBS with mental disorders and diseases. The database search was performed using Google Scholar and PubMed databases.

\section{ETIOPATHOGENESIS OF IBS}

The etiopathogenesis of IBS is multifactorial, as it depends on complex interactions between the immune, endocrine, and nervous systems [6,7]. The causes of IBS are not fully understood, but research done in the recent years sheds new light on the biological, genetic and psychosocial factors that may contribute to the development of IBS. The potential causes include visceral sensory dysfunction, abnormalities of the motor and secretory bowel functions, a history of infectious diarrhea, abnormalities in gut microbiota, and dysregulation of the brain-gut axis. Based on a variety of studies, authors consider the influence of the hypothalamic-pituitary-adrenal axis (HPA) and sex hormones on the regulatory mechanisms of the braingut axis [8]. Genetic susceptibility, with overlapping environmental and psychosocial factors, also seem to play a role in IBS [9].

\section{Microbiota abnormalities and post-infective factors}

Researchers argue that the composition of the gut microbiota of individuals with various diseases, including IBS, differs significantly from that of healthy people [10]. 
It is believed that the intestinal bacterial flora plays an important role in the pathogenesis of IBS [11]. This is borne out by the fact that IBS often occurs after intestinal infections or antibiotic treatment [12]. The gut microbiota can be modulated by signals flowing from the brain [13] and, conversely, microorganisms inhabiting the human gut can affect brain function, which testifies to the presence of a two-way homeostatic network [12].

Changes in microbial species composition of the gut have been observed in various subtypes of IBS. Both Lactobacillus and Bifidobacterium species have antiinflammatory effects in the gut; their depletion may lead to a mild inflammation. By contrast, an increased ratio of Firmicutes to Bacteroides can cause abdominal pain due to the production of large amounts of proteases. These microbiota abnormalities have been observed in IBS patients [14].

\section{Inflammation theory}

Compared to healthy controls, patients suffering from IBS have increased levels of pro-inflammatory cytokines (e.g. IL-6, IL-8, TNF-alpha, and IL-1beta) [15]. Changes in the intestinal immune system include activation of mast cells and $\mathrm{T}$ lymphocytes and altered gene expression leading to functional changes in the host's immune response to microbial pathogens [16]. Cytokines can affect the central nervous system (CNS) through various mechanisms:

- crossing into the brain at areas where the bloodbrain barrier is leaky,

- via active transport by cytokine-specific transport mechanisms, or

- by activating afferent nerve fibers, which transmit stimuli to the relevant regions of the brain, e.g. afferent vagal fibers that terminate in the nucleus tractus solitarius $[17,18]$.

\section{Dysfunction of the brain-gut axis}

The role of the brain-gut axis is to monitor and integrate the function of the gastrointestinal tract with the nervous system. This bidirectional crosstalk is supported by the central nervous system, the autonomic nervous system, the enteric nervous system, and the hypothalamic-pituitary-adrenal axis (HPA). The mechanisms underlying the transmission of signals along the brain-gut axis involve neural, immunological, and endocrine mediators $[19,20]$.

The HPA axis is an important element of the mechanisms regulating behavioral, neuroendocrine and autonomous responses to stress [21]. Several different hypotheses have been put forward about the relationship between the HPA axis and the dysfunctions associated with the irritable bowel syndrome. Environmental stress increases the level of proinflammatory cytokines, such as interleukin 1 (IL-1), interleukin 6 (IL-6), and tumor necrosis factor alpha (TNF-alpha). They activate the system through corticotropin-releasing hormone (CRH) secreted by the hypothalamus. CRH stimulates the pituitary gland to release adrenocorticotropic hormone (ACTH), whose target gland is the adrenal cortex. ACTH stimulates the synthesis and secretion of cortisol, a stress hormone that affects numerous organs, including the brain [19]. The level of pro-inflammatory cytokines is also increased in patients with sleep disorders, depression, and neurotic disorders [22].

$\mathrm{CRH}$ receptors are richly distributed both in the brain and peripheral organs. Injections of CRH enhance visceral sensation, increase intestinal permeability, and colonic hyperreactivity [23]. Excessively strong response to $\mathrm{CRH}$ is associated with both neurotic and depressive disorders [24]. Exposure to acute psychosocial stress results in extended activation of the HPA axis [25]. Chronic stress may lead to prolonged hypercortisolism, which may develop into hypocortisolism. In such circumstances, the adrenal glands remain hypertrophic, but secrete lower levels of cortisol. This increases the level of prostaglandins, which sensitize peripheral and central pain receptors, exacerbating the pain experienced by IBS patients [26].

The role of sex hormones in the symptomatology and pathophysiology of IBS has been investigated in connection with the higher prevalence of the disease among women and the relationship between IBS symptoms and a woman's hormonal status during the menstrual cycle, menstruation, pregnancy, and menopause [27]. Evidence gathered from various studies demonstrates that sex hormones affect the regulatory mechanisms of the brain-gut axis [28]. Sex hormones interact with other neurotransmitters - serotonin and corticotropin-releasing factor (CRF) [29]. A comparison of rectal sensitivity in different phases of the menstrual cycle shows that women with IBS are more sensitive during menstruation, compared to matched healthy controls [30]. Many women with IBS report exacerbation of symptoms in the perimenopausal period [31]. In addition, IBS is diagnosed more often in women with painful menstruation [32]. These studies indicate that changes in hormone levels have an effect on the prevalence and course of IBS.

Neurotrophins, such as nerve growth factor (NGF) or brain-derived neurotrophic factor (BDNF), are involved in visceral and somatic sensation and in the maturation, migration, and survival of neurons in the peripheral and central nervous systems. There are reports of massive release of NGF in response to psychosocial stress, aimed at integrating behavioral and neuroendocrine responses. 
Systemic administration of anti-NGF may prevent colonic hypersensitivity, meaning that NGF could be considered as a potential new therapeutic target [33].

There are also reports of increased expression of the proinflammatory cytokine TNF-alpha and reduced expression of the anti-inflammatory cytokines IL-10 and TGF-beta in IBS [34].

\section{Brain imaging changes}

IBS patients may show differences in the structure and function of the brain when compared to healthy control individuals. This may suggest the existence of a relationship between mental symptoms and IBS [35]. IBS patients who experience chronic pain show microstructural changes in the brain, especially in regions of the cerebral cortex associated with the integration of sensory information and corticothalamic modulation [36]. Brain imaging studies of IBS patients have also shown increased gray matter in the hypothalamus [37], which may be related to the excessive activity of the HPA axis. Also, decreased gray matter density was observed in the medial and ventrolateral prefrontal cortex, posterior parietal cortex, abdominal striatum, and thalamus [38]. Functional magnetic resonance imaging studies of IBS patients with moderately severe symptoms suggest that morphological changes occur primarily in brain regions associated with the processing of pain, emotions and visceral stimuli [39].

\section{Genetic susceptibility}

Despite some ambiguities, there is general agreement that IBS is a complex genetic syndrome. Thirty three [40] to forty two percent of IBS patients have a positive family history [41]. The syndrome has also been found to be more prevalent in monozygotic compared to dizygotic twins [42]. The results of these studies may suggest an association with a specific gene set or an environmental factor [43]. Recently, there have been many studies exploring the role of genetic factors in IBS. The focus of those studies has been on the relationship between gene polymorphisms and the manifestation of IBS symptoms. Gene polymorphisms involve the serotonergic, adrenergic and opioidergic systems as well as genes encoding proteins with immuno- and neuromodulatory functions [44].

One of the better-explored groups of potentially pathogenic genes are the genes associated with serotonergic mechanisms. Patients suffering from IBS have a different isoform of the serotonin re-uptake receptor in enterocyte cell membranes (SERT) and platelets. This is due to the lower expression of this protein, which results in lower serotonin uptake and increased gastrointestinal motility [45]. Mutations in the genes responsible for the synthesis of serotonin receptors (5-HT2A, 5-HT3A
5HT3D) are another important mechanism that may interfere with serotonin neurotransmission. Their higher expression may be associated with more severe pain in IBS patients [46].

\section{Psychosocial factors}

The biopsychosocial model [47] views IBS as a multidimensional disease, whose etiology and progression are governed by interactions between psychosocial and biological factors [48]. The concept that emotions can affect sensorimotor functions of the gastrointestinal tract goes back to the 19th century [49]. Currently, numerous clinical observations are being conducted regarding the influence of various psychoemotional disturbances on the onset and course of IBS. There is a wide range of psychosocial and environmental stressors which exert their influence at different moments of a person's life, but only susceptible individuals will develop IBS. Psychological factors seem to play a particularly important role as moderators of symptom severity and response to treatment [50].

The influence of stress on the symptoms of IBS is widely recognized by both clinicians and patients [51]. Patients with IBS report higher numbers of stressful life events than do healthy controls [52]. Factors that may contribute to the development of IBS symptoms include early childhood trauma, such as: experience of war [53], loss of a parent due to death, divorce or separation, or alcohol abuse by family members [54]. In patients, the occurrence of IBS is associated with a higher total early life trauma score and affects their health-related quality of life (HRQOL) [55].

People who experience violence are exposed to higher levels of mental stress [56] and report a higher level of somatization [57]. There are studies suggesting that experiences of violence are more frequently reported by patients with functional intestinal diseases than patients with organic bowel diseases or healthy controls [55,58]. Women who have experienced physical, sexual or verbal abuse are more likely to develop a dysfunction of the brain-gut axis and consequently develop IBS symptoms [59]. These studies strongly suggest that psychological or psychosocial stress determines the development of IBS.

The personality of patients is also taken into account as part of the etiology of IBS. Many studies draw attention to the higher levels of neuroticism in patients with IBS compared to the general population [60]. Neuroticism is a personality trait characterized by emotional instability and excessive reactivity to stressful situations. Neurotic people do not have well-shaped mechanisms for coping with stress, what results in excessive self-blame or attempts to escape from problems and going to functional education of gastrointestinal diseases. Neuroticism is an 
important predictor of disease perception and treatment outcomes [61].

\section{MANAGEMENT}

Irritable bowel syndrome is a symptom-based disease, which means treatment must involve elimination of symptoms, such as abdominal pain, spasms, bloating, diarrhea, and constipation [62]. Treatment includes non-pharmacological methods and pharmacotherapy. Management of IBS depends on good cooperation between doctor and patient. Non-pharmacological treatment includes psychotherapy, education, hypnotherapy, dietary modifications, and regular physical activity [63]. Dietary management consists mainly in the exclusion of certain foods. Patients are advised to limit the consumption of fats, raw vegetables, fruit, and caffeinated beverages [64]. They are also encouraged to keep food and symptom diaries. In this way, they can more readily identify the ingredient which exacerbates their symptoms.

Pharmacological treatment depends on IBS subtype and the coexistence of other disorders. The following groups of drugs are used in the treatment of IBS: cholinolytic drugs, opioid receptor antagonists, tricyclic antidepressants, serotonin 5-HT3 receptor antagonists and 5-HT4 agonists [65].

Most often IBS therapy focuses on preventing diarrhea (loperamide, probiotics, 5-HT3 receptor antagonists, binding agents) or constipation (swelling agents, chloride channel activators, osmotic laxatives, 5-HT4 receptor agonists, guanylate cyclase-C receptor agonists, softening agents, laxatives). The beneficial effect of a non-absorbable antibiotic, rifaximin, has been demonstrated in diarrhea-predominant IBS [66].

When IBS symptoms are associated with psychiatric conditions - most often depressive, anxiety and bipolar disorders - psychotropic drugs are included in the treatment to alleviate the primary cause of the disorder. Benzodiazepines, TLPD, and selective serotonin receptor inhibitors are used [67]. Cases of depression and insomnia are treated with amitriptyline. This drug (or paroxetine, as an alternative) is also indicated for patients with chronic abdominal pain [68].

\section{IBS AND SOMATIZATION}

IBS requires comprehensive treatment. It meets the criteria for somatic symptom (somatoform) disorder, which points to a possible association of the syndrome with psychological factors [69].

The origin of the symptoms may be either psychogenic or organic. Somatic complaints with no demonstrable organic findings present a diagnostic and therapeutic challenge [70]. Approximately 50\% of IBS patients report additional somatic and mental symptoms

\section{$[71,72]$.}

Abdominal pain, diarrhea, nausea, heartburn, fatigue, pollakiuria or dyspareunia may require consultation with a psychiatrist [73].

Patients with IBS report not only somatic but also psychiatric symptoms. These include mainly depressive symptoms (fatigue, sleep problems, lack of appetite) as well as anxiety symptoms (anxiety, rumination, and panic attacks) [74,75].

According to DSM-5 from 2013, somatoform disorders make up a category that is on the borderline between psychiatry and other areas of medicine [70]. A psychiatric diagnosis in somatoform diseases may explain the complaints, but it also suggests that the physical ailments have a solely psychiatric background, thus bearing the risk of overlooking a serious illness [76].

Another problem associated with the heterogeneous nature of somatic symptom disorders is that they generate high diagnostic and therapeutic costs as they require multispecialty diagnosis and pharmacological and psychotherapeutic management [71].

"Somatization" is defined as the tendency to convert mental distress to physical pain, which prompts the patient to seek medical assistance. Somatization is an important psychological factor directly related to the severity of IBS .

According to van Oudenhove's research, increased levels of anxiety, depression and somatization increase both pre- and post-prandial symptoms in IBS patients [74].

IBS has a variable and ambiguous etiology and pathomechanism and is strongly related to the patient's mental health and psychological traits [70].

\section{IBS AND MENTAL DISEASES}

In recent years, there have been many studies on the co-morbidity of IBS with mental disorders. The estimated incidence of mental disorders in IBS patients varies from $40 \%$ to $90 \%$ and is higher than in the general population [77,78]. Also, the incidence is higher among patients who seek medical assistance [79]. IBS patients are most commonly diagnosed with affective disorders (depression, dysthymia) and anxiety disorders (panic disorder, generalized anxiety disorder) [78]. There are no data showing that the individual forms of IBS predispose patients to specific mental illnesses [80]. In addition, it has been proven that people diagnosed with IBS have a higher risk for depression, anxiety disorders, sleep disorders, and bipolar disorders [81]. Authors still emphasize the importance of interaction between mental disorders and IBS, which should be taken into account in the development of screening and treatment strategies [78].

Research reports confirm that patients with IBS have higher levels of both anxiety and depression, compared 
to healthy controls [80]. Some evidence suggests that anxiety may be more evident at an early stage of IBS, while depression symptoms are more common in chronically ill patients [79]. Both anxiety and depressive disorders are statistically significantly more common in patients with IBS [77]. According to available literature, patients with IBS have a higher prevalence of anxiety disorders ( $47 \%$ vs. $26 \%$ ) and depressive disorders (33\% vs. 16\%) compared to the general population [77]. As far as anxiety disorders are concerned, IBS research is focused mainly on generalized anxiety disorder and panic disorder. With regard to depressive disorders, authors mainly investigate the relationship between IBS and depression [78].

From 25 to $44 \%$ of patients with IBS symptoms have a comorbid panic disorder. Studies of the relationship between panic disorder and IBS show that the two conditions have a common mechanism, i.e. an increased level of cortisol and impaired immune system function (increased levels of cytokines). There is evidence that avoidance behaviors due to the fear of IBS symptoms may be associated with severe forms of agoraphobia, giving rise to subsequent depressive symptoms [78].

It seems that there is also a connection between factors that cause post-traumatic stress disorder (PTSD) and IBS. A significantly increased risk of IBS has been demonstrated among war veterans, mainly women. Many studies investigate sexual abuse as one of the reasons for developing IBS symptoms and confirm the increased risk of IBS in sexually abused individuals [78].

Depression is one of the most commonly diagnosed psychiatric disorders in patients with IBS. It is estimated that the prevalence of IBS in people with depression can be around 27-47.3\% [78] up to even 59\% [82]. People diagnosed with IBS have also been found to have significantly higher risk ratios for developing depressive symptoms. The risk is the highest within one year of IBS diagnosing, but it remains statistically significant for more than five years after the diagnosis [81].

In the studies conducted so far, there is usually no significant relationship between bipolar disorder and IBS [78]. However, some of them described that IBS is associated with an increased risk of developing bipolar disorder in the future [81]. However, so far there is not enough research to confirm the relationship between bipolar affective disorder and irritable bowel syndrome.

In the case of schizophrenia, the frequency of comorbidity of IBS symptoms may be greater than previously reported, due to the fact that the majority of patients with schizophrenia speak about IBS symptoms only when asked about them. In addition, schizophrenia is associated with a high risk of developing many somatic diseases, what complicates the assessment of comorbidity of IBS in patients with schizophrenia. There are conflicting data on the relationship between IBS and schizophrenia. Different studies provide different correlation coefficients, which usually range from 17-19\% [78]. In one study, no statistically significantly high risk of schizophrenia was found in patients previously suffering from IBS [81].

IBS has also been found to increase the risk of newly diagnosed sleep disorder, which is explained by a common pathomechanism (changes in the level of inflammatory cytokines, such as interleukin 1 and 6 or the level of melatonin) [81]. However, further investigations are required to confirm this relationship.

Both IBS and mental disorders are multifactorial. Their development is influenced by psychological, environmental, and genetic factors [81]. Further research is needed to determine the causes of comorbidity of IBS and mental disorders.

It should be remembered that more frequent diagnoses of mental disorders in IBS patients may result from the fact that these individuals regularly seek medical advice [81]. Patients with IBS often report psychological symptoms in addition to somatic symptoms. They are mainly depression-related symptoms (fatigue, sleeping problems, lack of appetite) and anxiety-related symptoms (anxiety, nervousness, panic attacks). As a result, many patients with IBS are found to meet the criteria for the respective mental disorders or suffer from prodromal symptoms of these diseases. It is also possible that sleep disorders, depression, and anxiety are a reaction to stress associated with IBS diagnosis. It is recommended that psychiatric symptoms, especially symptoms of depression and anxiety, be systematically monitored and treated, because psychological factors may influence the severity of IBS symptoms, their persistence and response to treatment [82].

zaliczaną do czynnościowych zaburzeń żołądkowojelitowych. Objawami charakterystycznymi dla IBS są: przewlekły ból brzucha i zmiany nawyków jelitowych [1]. Część pacjentów z IBS oprócz objawów żołądkowojelitowych, zgłasza również pozajelitowe objawy somatyczne, ale również objawy psychiczne (męczliwość, zaburzenia snu, utratę apetytu, niepokój itp.) [2]. Szacuje się, że częstość występowania IBS w populacji ogólnej 
wynosi ok. 10-20\%, przy czym najwyższą zachorowalność obserwuje się w wieku od 30 do 40 lat. Ok. 2-krotnie częściej choroba ta dotyczy kobiet, a niektóre badania wykazują nawet 3 lub 4 razy większe rozpowszechnienie IBS wśród kobiet w porównaniu z mężczyznami [3].

Zespół jelita drażliwego rozpoznaje się po wykluczeniu choroby organicznej układu pokarmowego. Postawienie rozpoznania opiera się o tzw. Kryteria Rzymskie IV z 2016 roku [4].

Według nich zespół jelita drażliwego można zdiagnozować, gdy u pacjenta występuje nawracający ból brzucha trwający średnio przez conajmniej 1 dzień w tygodniu przez ostatnie 3 miesiące. Pierwsze objawy zazwyczaj mają miejsce około 6 miesięcy przed rozpoznaniem. Ten okres pozwala na uznanie choroby za przewlekłą. Aby można było zdiagnozować schorzenie jako IBS, ból musi ponadto spełniać co najmniej dwa spośród trzech poniższych kryteriów:

- związany jest z wypróżnieniem,

- związany jest ze zmianą częstości wypróżnień

- związany jest ze zmianą konsystencji stolca [4].

Podstawę diagnostyki IBS stanowi wykluczenie choroby organicznej.

W zależności od dominujących objawów IBS można podzielić na:

- IBS z zaparciami (IBS with constipation, IBS-C)

- IBS z biegunką (IBS with diarrhea, IBS-D)

- postać mieszana (Mixed IBS, IBS-M)

- postać niezróżnicowana (Unsubtyped IBS, IBS-U) $[1,4]$.

Do tej pory nie jest w pełni poznana pierwotna przyczyna IBS. W etiologii IBS pod uwagę bierze się wiele czynników, głownie interakcje między czynnikami biologicznymi i psychospołecznymi. Wśród teorii związanych z patofizjologią tego zespołu wymienia się: zmiany w OUN, zaburzenia osi podwzgórze-przysadkanadnercza, teorię zapalną, czynniki poinfekcyjne, zaburzenia mikrobioty jelitowej, nadwrażliwość trzewną, podatność genetyczną, zaburzenia układu odpornościowego oraz czynniki psychospołeczne [1,5].

Ta wieloczynnikowa patogeneza niesie za sobą konieczność interdyscyplinarnego spojrzenia na problem diagnostyki i leczenia pacjentów z IBS.

W artykule dokonano przeglądu, dostępnych w bazach Google Scholar i PubMed, badań i prac łączących zagadnienie, jakim jest IBS z aspektami psychiatrycznymi tj. wspólną dla IBS i zaburzeń psychicznych etiopatogenezę, pojęcia somatyzacji w kontekście IBS oraz współwystępowanie chorób i zaburzeń psychicznych z zespołem jelita drażliwego.

\section{ETIOPATOGENEZA IBS}

Etiopatogeneza zespołu jelita drażliwego posiada wieloczynnikowy charakter, oparty na złożonych interakcjach między układem odpornościowym, hormonalnym i nerwowym [6,7]. Nie została dotychczas dokładnie poznana, ale badania ostatnich lat rzucają nowe światło na czynniki biologiczne, genetyczne i psychospołeczne mogące mieć wpływ na rozwój IBS. Wśród potencjalnych przyczyn najbardziej popularne są: zaburzenia czucia trzewnego, czynności motorycznej i wydzielniczej jelit, przebycie biegunki infekcyjnej i zaburzenia mikroflory oraz dysregulacja osi mózg-jelito. Bazując na różnorodnych badaniach, rozważa się wpływ osi podwzgórze-przysadka-nadnercza (hypothalamicpituitary-adrenal axis, HPA) oraz hormonów płciowych na mechanizmy regulacyjne osi mózg-jelito [8]. Podłożem występowania IBS może być również skłonność genetyczna, na którą nakładają się czynniki środowiskowe i psychospołeczne [9].

\section{Zaburzenia mikroflory i czynniki poinfekcyjne}

Badacze dowodzą, że skład mikroflory jelitowej osób z różnymi schorzeniami, między innymi w IBS różni się istotnie od osób zdrowych [10]. Uważa się, że flora bakteryjna jelit odgrywa ważną rolę w patogenezie IBS [11]. Wynika to choćby z faktu, że IBS występuje często po infekcjach jelitowych lub leczeniu antybiotykami [12]. Flora bakteryjna jelit może być modulowana poprzez sygnały płynące ze strony mózgu [13] oraz mikroflora jelit może wpłynąć na funkcjonowanie mózgu, co przemawia za obecnością dwukierunkowej sieci homeostatycznej [14].

Zmiany mikrobioty obserwuje się w różnych podtypach IBS. Bakterie $\mathrm{z}$ rodzaju Lactobacillus, jak i Bifidobacterium mają działanie przeciwzapalne w jelitach; ich wyczerpanie może przyczynić się do niskiego stopnia stanu zapalnego. Natomiast zwiększony stosunek Firmicutes do Bacteroides może powodować bóle brzucha z powodu produkcji dużej ilości proteaz. Powyższe zaburzenia mikrobioty obserwuje się u pacjentów omawianej grupy chorych [15].

\section{Teoria zapalna}

U pacjentów z IBS $\mathrm{w}$ porównaniu z grupami kontrolnymi podwyższone są poziomy cytokin prozapalnych (np. IL-6, IL-8, czynnik TNF-alfa i IL-1beta) [11]. Zmiany układu odpornościowego w obrębie jelit obejmują aktywację komórek tucznych i limfocytów $\mathrm{T}$ oraz zmienioną ekspresję genów w funkcjonalnych zmianach odpowiedzi immunologicznej gospodarza na patogeny drobnoustrojów [16]. Cytokiny mogą wywierać wpływ na ośrodkowy układ nerwowy (OUN) kilkoma drogami:

- Przechodząc przez przepuszczające rejony w obrębie bariery krew-mózg, 
- Za pomocą aktywnego transportu przez specyfi-czne dla cytokin mechanizmy transportowe,

- Przez aktywację aferentnych włókien nerwowych, np. nerwu błędnego, które przesyłają bodźce do odpowiednich rejonów mózgu, np. jądra pasma samotnego $[17,18]$.

\section{Dysfunkcja „osi mózg-jelito”}

Rolą osi mózg-jelito jest monitorowanie oraz integracja funkcji przewodu pokarmowego z układem nerwowym. Jej dwukierunkowe działanie zapewnione jest poprzez ośrodkowy układ nerwowy, autonomiczny układ nerwowy, jelitowy układ nerwowy oraz oś podwzgórzeprzysadka-nadnercza (hypothalamic-pituitary-adrenal axis, HPA). Mechanizmy leżące u podstaw komunikacji osi mózg-jelito obejmują mediatory neuronalne, immunologiczne oraz hormonalne $[19,20]$.

Oś HPA jest ważnym elementem mechanizmów regulujących zachowania behawioralne, neuroendokrynne i autonomiczne $w$ odpowiedzi na stres [21]. Postawiono kilka różnych hipotez na temat związku pomiędzy osią HPA a dysfunkcjami w przebiegu zespołu jelita drażliwego.

Stres środowiskowy podnosi poziom prozapalnych cytokin, takich jak interleukina 1 (IL-1), interleukina 6 (IL-6), czynnik martwicy nowotworów alfa (TNFalfa). Aktywują one system poprzez kortykoliberynę (corticotropin-releasing-hormone, $\mathrm{CRH}$ ) uwalnianą z podwzgórza. Pobudza ona przysadkę do wydzielania hormonu adrenokortykotropowego (ACTH). Gruczołem docelowym tego hormonu jest kora nadnerczy. ACTH stymuluje syntezę oraz wydzielanie kortyzolu - jednego z hormonów stresu, wywierającego wpływ na wiele organów, w tym mózg [19]. Poziom cytokin prozapalnych podniesiony jest również u pacjentów z zaburzeniami snu, depresją i zaburzeniami nerwicowymi [22].

Receptory CRH są bogato rozmieszczone zarówno w mózgowiu jak i narządach obwodowych. Iniekcje z CRH skutkują wzrostem czucia trzewnego, wzrostem przepuszczalności jelit oraz nadreaktywnością okrężnicy [23]. Nadmierna odpowiedź na CRH związana jest zarówno z występowaniem zaburzeń nerwicowych, jak i depresji [24]. Narażenie na ostry stres psychospołeczny skutkuje przedłużoną aktywacją osi HPA [25]. Chroniczny stres prowadzić może do długotrwałego hiperkortyzolizmu, który może rozwijać się w hipokortyzolizm ze zużycia. W takich okolicznościach nadnercza pozostają hipertroficzne, ale wydzielają niższe ilości kortyzolu. Podnosi to poziom prostaglandyn, które uczulają obwodowe i ośrodkowe receptory bólu, nasilając dolegliwości bólowe w przebiegu IBS [26].

Rola hormonów płciowych w symptomatologii oraz patofizjologii IBS rozpatrywana jest na podstawie większego rozpowszechnienia choroby wśród kobiet oraz związku między objawami a statusem hormonalnym podczas fazy cyklu, menstruacji, ciąży lub menopauzy [27]. Na podstawie różnorodnych badań został zaobserwowany wpływ hormonów płciowych na mechanizmy regulacyjne osi mózg-jelito [28]. Hormony płciowe wykazują szereg interakcji z innymi neurotransmiterami - serotoniną oraz czynnikiem uwalniającym hormon kortykotropowy (kortykoliberyną - CRF corticotropin-releasing factor) [29]. Porównując wrażliwość odbytnicy w różnych fazach cyklu miesiączkowego, kobiety z IBS są bardziej wrażliwe podczas menstruacji, w stosunku do zdrowej grupy kontrolnej [30]. Wiele kobiet z IBS zgłasza zaostrzenia objawów w okresie okołomenopauzalnym [31]. Dodatkowo IBS zdiagnozowany jest częściej u kobiet z bolesnymi miesiączkami [32]. Badania te wskazują, że zmiany $w$ poziomach hormonów mają wpływ na częstość występowania oraz przebieg IBS.

Neurotrofiny, takie jak czynnik wzrostu nerwów (nerve growth factor - NGF) lub neurotroficzny czynnik pochodzenia mózgowego (brain-derived neurotrophic factor - BDNF) zaangażowane są w czucie trzewne i somatyczne oraz $w$ proces dojrzewania, migracji i przeżycia neuronów w obwodowym i ośrodkowym układzie nerwowym. Badania donoszą

o masywnym uwalnianiu NGF w odpowiedzi na stres psychospołeczny, w celu integracji odpowiedzi behawioralnej i neuroendokrynnej. Ogólnoustrojowe podawanie anty-NGF może zapobiegać nadwrażliwości jelita grubego i uważane jest za potencjalnie nowy cel terapeutyczny [33].

Istnieją również badania wykazujące zwiększoną ekspresję cytokiny prozapalnej TNF-alfa oraz mniejszą ekspresję cytokin przeciwzapalnych IL-10 oraz TGF-beta [34].

\section{Zmiany w obrazowych badaniach mózgu}

Pacjenci z IBS mogą wykazywać różnice w budowie i funkcjonowaniu mózgowia w porównaniu ze zdrowymi grupami kontrolnymi. Może to sugerować związek między objawami psychicznymi a IBS [35]. Pacjenci z IBS doświadczający przewlekłego bólu wykazują zmiany mikrostruktur w mózgu, szczególnie w obszarach kory mózgowej związanych $\mathrm{z}$ integracją informacji sensorycznej i modulacji korowo-wzgórzowej [36]. Badania obrazowe u pacjentów z IBS wykazały również zwiększenie ilości istoty szarej w okolicy podwzgórza [37], co może mieć związek z nadmierną aktywnością osi HPA. Mniejszą gęstość istoty szarej zaobserwowano z kolei w okolicy przyśrodkowej i brzusznobocznej kory przedczołowej, tylnej kory ciemieniowej, prążkowiu brzusznym oraz wzgórzu [38]. Funkcjonalne badania rezonansu magnetycznego u pacjentów z IBS 
o umiarkowanym nasileniu objawów sugerują, że zmiany morfologiczne występują przede wszystkim w rejonach mózgu związanych z przetwarzaniem bólu i emocji oraz bodźców trzewnych [39].

\section{Uwarunkowania genetyczne}

Pomimo pewnych niejasności, istnieje ogólna zgoda co do hipotezy, że IBS jest złożonym zespołem genetycznym. Pacjenci chorujący na zespół jelita drażliwego często posiadają pozyty wny wywiad rodzinny, wahający się od 33\% [40] do 42\% [41]. Wykazano również wyższą częstość występowania zespołu u bliźniąt monozygotycznych niż dizygotycznych [42]. Wyniki tych badań mogą sugerować wspólny związek ze specyficznym zestawem genów lub z czynnikiem środowiskowym [43]. W ostatnim czasie pojawiło się wiele badań szukających związku między uwarunkowaniami genetycznymi a występowaniem IBS. Koncentrowały się one na relacjach między polimorfizmem genów a manifestacją objawów IBS. Polimorfizm genów obejmuje układy serotoninergiczny, adrenergiczny i opioidoergiczny oraz kodowanie białek o funkcjach immuno- i neuromodulujących [44].

Jedną z dobrze poznanych grup genów, potencjalnie chorobotwórczych, są geny związane z mechanizmami serotoninergicznymi. U grupy pacjentów chorujących na IBS występuje inna izoforma receptora dla zwrotnego wychwytu serotoniny w błonach komórkowych enterocytów (SERT) i płytek krwi. Wynika to z mniejszej ekspresji tego białka, co skutkuje mniejszym wychwytem serotoniny i zwiększeniem motoryki przewodu pokarmowego [45]. Mutacje w genach odpowiedzialnych za syntezę receptorów serotoniny (5-HT2A, 5-HT3A, 5HT3D) są innym ważnym mechanizmem, który może zakłócać przekaźnictwo serotoniny. Wyższa ich ekspresja może być związana $\mathrm{z}$ silniejszymi dolegliwościami bólowymi u pacjentów z IBS [46].

\section{Czynniki psychospołeczne}

Odwołując się do modelu biopsychospołecznego [47], IBS postrzegany jest jako choroba wielowymiarowa, wynikająca z interakcji między czynnikami psychospołecznymi i biologicznymi w etiologii i progresji choroby [48]. Koncepcja, że emocje mogą wpływać na funkcje sensomotoryczne przewodu pokarmowego ma swój początek w XIX wieku [49]. Obecnie prowadzone są liczne obserwacje kliniczne, dotyczące wpływu różnorodnych zaburzeń psychoemocjonalnych na wystąpienie i przebieg zespołu jelita drażliwego. Występuje szeroki zakres stresorów psychospołecznych oraz środowiskowych, działających w różnych momentach życia, ale tylko u osób podatnych rozwinie się zespół jelita drażliwego. Czynniki psychologiczne wydają się odgrywać szczególnie istotną rolę jako moderatory nasilenia objawów oraz odpowiedzi na leczenie [50].

Wpływ stresu na objawy zespołu jelita drażliwego jest powszechnie uznawany zarówno przez klinicystów, jak i pacjentów [51]. Pacjenci z IBS zgłaszają większą ilość sytuacji stresowych niż zdrowe grupy kontrolne [52]. Do czynników mogących przyczynić się do rozwinięcia objawów IBS możemy zaliczyć sytuacje stresowe pojawiające się we wczesnym dzieciństwie, takie jak: doświadczenie wojny [53], utrata rodzica z powodu śmierci, rozwodu lub separacji, wychowywanie się w rodzinie nadużywającej alkoholu [54]. U pacjentów występowanie IBS wiąże się z wyższym całkowitym wynikiem w skali ciężkości urazów w dzieciństwie (early life trauma score) i wpływa na jakość życia związaną ze zdrowiem (HRQOL - health related quality of life) [55].

Osoby doświadczające przemocy narażone są na wyższy poziom stresu psychicznego [56] oraz wyższy poziom somatyzacji [57]. Istnieją badania sugerujące, że doświadczenie przemocy jest częstsze u pacjentów z funkcjonalnymi chorobami jelit niż u pacjentów z chorobami na podłożu organicznym lub zdrowymi grupami kontrolnymi [56, 58]. Kobiety, które doświadczyły fizycznej, seksualnej i słownej przemocy, są bardziej narażone na rozwinięcie dysfunkcji osi mózg-jelito, a w konsekwencji rozwinięcie objawów IBS [59]. Badania te silnie i wyraźnie sugerują, że stres psychologiczny lub psychospołeczny determinuje rozwój IBS.

W etiologii IBS brana pod uwagę jest również osobowość pacjentów. Wiele badań zwraca uwagę na wyższy poziom neurotyzmu u pacjentów z IBS w porównaniu z populacją ogólną [60]. Neurotyzm to cecha osobowości charakteryzująca się niestabilnością emocjonalną oraz nadmierną reaktywnością na sytuacje stresowe. Osoby neurotyczne nie posiadają odpowiednio ukształtowanych mechanizmów radzenia sobie ze stresem, co skutkuje nadmiernym obwinianiem się lub próbami ucieczki od problemów, a w konsekwencji wykształcenia czynnościowych chorób przewodu pokarmowego. Neurotyczność jest ważnym predyktorem postrzegania choroby oraz efektów leczenia [61].

\section{POSTĘPOWANIE}

Zespół jelita drażliwego jest chorobą opartą na symptomach, leczenie więc opiera się na niwelowaniu objawów, takich jak: bóle brzucha, skurcze, wzdęcia, biegunki, zaparcia [62]. Leczenie obejmuje stosowanie metod niefarmakologicznych oraz farmakoterapię. Podstawą leczenia IBS jest dobra współpraca między lekarzem a chorym. Postępowanie niefarmakologiczne obejmuje psychoterapię, edukację, hipnoterapię, modyfikacje dietetyczne oraz regularną aktywność fizyczną [63]. Postępowanie dietetyczne polega głównie 
na stosowaniu diety eliminacyjnej. Poleca się ograniczenie spożywania tłuszczów, surowych warzyw, owoców, napojów z kofeiną [64]. Zalecane jest również prowadzenie dzienniczków żywieniowych i występujących objawów. W ten sposób łatwiej zidentyfikować składnik pokarmowy odpowiedzialny za zaostrzenie objawów.

Leczenie farmakologiczne uzależnione jest od podtypu IBS oraz współwystępowania innych zaburzeń. W leczeniu stosowane są następujące grupy leków: leki cholinolityczne, antagoniści receptora opioidowego, trójcykliczne leki przeciwdepresyjne, antagoniści receptorów serotoninowych 5-HT3 oraz agoniści 5-HT4 [65].

Najczęściej terapia w IBS koncentruje się na zapobieganiu biegunkom (stosujemy np. loperamid, probiotyki, antagonistów receptora 5-HT3, preparaty wiążące) lub zaparciom (środki pęczniejące, aktywatory kanałów chlorkowych, osmotyczne środki przeczyszczające, agoniści receptora 5-HT4, agoniści receptorów cyklazy guanylowej C, preparaty zmiękczające, preparaty przeczyszczające). W IBS z biegunką wykazano korzystne działanie niewchłanialnego antybiotyku - ryfaksyminy [66].

W przypadku stwierdzonych zaburzeń psychicznych, najczęściej zaburzeń depresyjnych, lękowych, choroby afektywnej dwubiegunowej, do leczenia włączane są leki psychotropowe celem minimalizacji pierwotnej przyczyny zaburzeń. Stosowane są benzodiazepiny, TLPD a także selektywne inhibitory receptora serotoninowego [67]. W przypadku depresji i bezsenności stosuje się amitryptylinę. Lek ten zaleca się także u chorych z przewlekłym bólem brzucha (alternatywnie paroksetyna)[68].

\section{SOMATYZACJA A IBS}

Zespół jelita drażliwego jest jednostką chorobową wymagającą kompleksowego traktowania. Spełnia on kryteria zaburzenia somatyzacyjnego, co wskazuje jako możliwą przyczynę zespołu - czynnik ze sfery psychicznej [69].

Doświadczane objawy mają pochodzeie psychogenne, a dolegliwości somatyczne bez widocznego podłoża organicznego stanowią wyzwanie diagnostyczne i terapeutyczne [70]. Ok. 50\% pacjentów z IBS zgłasza objawy somatyczne i psychiczne [71,72].

Ból brzucha, biegunka, nudności, zgaga, zmęczenie, częstomocz czy dyspareunia mogą w takim wypadku zakończyć się konsultacją u lekarza specjalisty z dziedziny psychiatrii. [73].

Pacjenci z IBS zgłaszają nie tylko pozajelitowe objawy somatyczne, ale także psychiczne. Należą tu głównie objawy depresyjne (zmęczenie, problemy ze snem, brak apetytu), jak również lękowe (niepokój, rozdrażnienie, lęk) $[74,75]$.

Wg DSM-5 z 2013 r. zaburzenia pod postacią somatyczną to kategoria pozostająca $\mathrm{w}$ zawieszeniu pomiędzy psychiatrią a pozostałymi dziedzinami medycyny [70]. Diagnoza psychiatryczna może służyć jako (wątpliwe) uzasadnienie skarg, ale też sugerować, że dolegliwości fizyczne stanowią wyłącznie psychiatryczny problem i przyczynić się do przeoczenia poważnej choroby [76].

Problemem wynikającym z niejednorodnej natury zaburzenia jest również generowanie wysokich kosztów diagnostyczno-leczniczych związanych z postępowaniem farmakologicznym, psychoterapeutycznym oraz wielospecjalizacyjną diagnostyką [71]

„Somatyzację" definiuje się jako skłonność do odczuwania i przenoszenia cierpienia psychicznego w postaci objawów somatycznych objawów somatycznych, które skłaniają pacjenta do szukania pomocy medycznej. Somatyzacja jest istotnym czynnikiem psychologicznym bezpośrednio związanym z nasileniem IBS.

Wg badań van Oudenhove'a zwiększony poziom lęku, depresji i somatyzacji jest związany z nasileniem dolegliwości zarówno przed-, jak i poposiłkowych u pacjentów z IBS [74].

IBS charakteryzuje zmienność i niejednoznaczność pod względem etiologii i patomechanizmu oraz związek ze stanem psychicznym i podatnością na stres u pacjenta [70].

\section{CHOROBY PSYCHICZNE A IBS}

W ostatnich latach wielokrotnie badano współwystępowanie chorób i zaburzeń psychicznych w grupach pacjentów cierpiących na IBS. Szacuje się, że współczynnik rozpowszechnienia zaburzeń psychicznych wśród tych chorych waha się od $40 \%$ do 90\% i jest większy niż w populacji ogólnej [77,78]. Przy czym odsetek ten jest wyższy gdy badaną grupą chorych stanowili pacjenci, którzy sami zgłaszali się po pomoc medyczną [79]. Najczęściej diagnozowane są: zaburzenia afektywne (depresja, dystymia) i zaburzenia lękowe (lęk paniczny, uogólnione zaburzenia lękowe) [77]. Nie wykazano jednak, aby któraś z postaci IBS wiązała się z większym prawdopodobieństwem współwystępowania danej choroby psychicznej [80]. Dodatkowo udowodniono, że u osób z rozpoznaniem IBS ryzyko rozwoju zaburzeń depresyjnych, lękowych, zaburzeń snu i zaburzeń afektywnych dwubiegunowych jest większe [81]. Nadal podkreśla się wagę interakcji między zaburzeniami psychicznymi a IBS, co ma znaczenie przy opracowywaniu strategii badań przesiewowych i leczenia [78].

Przeprowadzone badania potwierdzają większe nasilenie zarówno lęku, jak i depresji u pacjentów z IBS w porównaniu do osób zdrowych [79]. Niektóre 
dowody wskazują, że lęk może być widoczny częściej na wczesnym etapie IBS, podczas gdy objawy depresji występują częściej u pacjentów cierpiących przewlekle [79]. Zarówno zaburzenia lękowe, jak i depresyjne występują statystycznie istotnie częściej u chorych $\mathrm{z}$ IBS [77]. Zgodnie $\mathrm{z}$ dostępnym piśmiennictwem u pacjentów z zespołem jelita drażliwego występuje większe rozpowszechnienie zaburzeń lękowych (47\% vs. $26 \%$ ) i zaburzeń depresyjnych (33\% vs. 16\%) względem populacji ogólnej [77]. Wśród zaburzeń lękowych największą uwagę zwraca się na uogólnione zaburzenia lękowe oraz zespół lęku panicznego. Natomiast wśród zaburzeń depresyjnych głównie poszukuje się związku między depresją a IBS [78].

Zespół lęku panicznego współwystępuje u 25 do 44\% pacjentów z objawami zespołu jelita drażliwego [78]. Próbowano wyjaśnić związek między zespołem lęku panicznego i IBS. Badania wskazują m.in. na wspólny mechanizm, tj. podwyższony poziom kortyzolu i zaburzone funkcjonowanie układu odpornościowego (zwiększone poziomy cytokin) [78]. Istnieją dowody, że występowanie zachowań unikowych związanych z obawą przed objawami IBS może wiązać się z ciężką postacią agorafobii, jak również $\mathrm{z}$ następczymi zaburzeniami depresyjnymi [78].

Wydaje się, że istnieje również związek między czynnikami wywołującymi zespół stresu pourazowego a IBS. Nie jest on jednak do końca poznany. Udowodniono istotnie zwiększone ryzyko zachorowania na IBS wśród weteranów, głównie płci żeńskiej. Wiele badań bierze pod uwagę głównie nadużycia seksualne jako jedną z przyczyn rozwinięcia objawów IBS i potwierdza zwiększone ryzyko wystąpienia IBS w tych przypadkach [78].

Depresja jest jednym z najczęściej diagnozowanych zaburzeń psychiatrycznych u pacjentów z IBS. Szacuje się, że częstość występowania IBS u osób cierpiących na depresję może wynosić ok. 27-47,3\% [78] do nawet $59 \%$ [82]. U osób ze zdiagnozowanym IBS udowodniono również znacznie wyższe ryzyko rozwoju zaburzeń depresyjnych $\mathrm{w}$ przyszłości. Najwyższe ryzyko występuje w ciągu roku od rozpoznania IBS, ale pozostaje statystycznie istotne przez ponad pięć lat po postawieniu diagnozy [82].

W prowadzonych do tej pory badaniach stwierdzano zwykle brak istotnej zależności między chorobą afektywną dwubiegunową a IBS [78]. Natomiast niektóre z nich opisywały, że IBS wiąże się ze zwiększonym ryzykiem rozwoju zaburzenia afektywnego dwubiegunowego w przyszłości [81]. Nie ma jednak wystarczająco dużej ilości badań aby potwierdzić związek między chorobą afektywną dwubiegunową i zespołem jelita drażliwego.

W przypadku schizofrenii częstość współwystępowania objawów IBS może być większa niż dotychczas wykazywano, ze względu na to, że większość pacjentów ze schizofrenią mówi o objawach IBS tylko w przypadkach, kiedy zostaną o to zapytani. Dodatkowo, schizofrenia wiąże się z wysokim ryzykiem rozwoju wielu chorób somatycznych, co komplikuje ocenę współistnienia IBS u pacjentów chorujących na schizofrenię. Istnieją sprzeczne dane na temat związku IBS ze schizofrenią. Korelacja obu zaburzeń w zależności od badania jest różna. Zwykle wynosi 17-19\% [78]. W jednym z badań nie stwierdzono istotnego wysokiego ryzyka zachorowania na schizofrenię u pacjentów wcześniej chorujących na IBS [81].

IBS zwiększa również ryzyko ujawnienia się zaburzeń snu, co tłumaczy się wspólnym patomechanizmem (zmianami poziomu zapalnych cytokin, takich jak interleukina 1 i 6 lub też poziomem melatoniny). Wymaga to jednak dalszych prac potwierdzających ten związek [81].

Zaburzenia psychiczne mają charakter wieloczynnikowy. Czynniki psychologiczne, środowiskowe i genetyczne wpływają na rozwój zarówno IBS, jak i zaburzeń psychicznych [81]. Konieczne są dalsze badania określające przyczyny współwystępowania IBS i zaburzeń psychicznych.

Należy pamiętać, że częstsze diagnozowanie zaburzeń psychicznych może wynikać z regularnego korzystania z opieki medycznej u pacjentów z IBS [81]. Pacjenci z IBS często, prócz objawów somatycznych, zgłaszają również objawy psychiczne. Głównie są to objawy zespołu depresyjnego (zmęczenie, problemy ze snem, brak apetytu) oraz lęku (niepokój, nerwowość, ataki paniki). Przez to wielu pacjentów z IBS spełnia kryteria odpowiednich zaburzeń psychicznych lub cierpi na objawy prodromalne tych chorób [82]. Możliwe jest również, że zaburzenia snu, depresyjne i lękowe są reakcją na stres związany z diagnozą IBS. Zaleca się aby objawy psychiatryczne, szczególnie objawy depresji i lęku, były systematycznie monitorowane i leczone, ponieważ czynniki psychologiczne mogą wpływać na nasilenie objawów IBS, ich uporczywość i odpowiedź na zastosowane leczenie [82] 


\section{Conflict of interest}

The authors have declared no conflict of interest.

\section{References:}

1. Fadgyas-Stanculete M. et al.: The relationship between irritable bowel syndrome and psychiatric disorders: from molecular changes to clinical manifestations. Journal of Molecular Psychiatry 2014; 2 (1): 4

2. Hausteiner-Wiehle C., Henningsen P.: Irritable bowel syndrome: relations with functional, mental, and somatoform disorders. World journal of gastroenterology: WJG 2014; 20 (20): 60246030

3. Grzesiak M., et al.: The Lifetime Prevalence of Anxiety Disorders Among Patients with Irritable Bowel Syndrome. Advances in Clinical and Experimental Medicine 2014; 23 (6): 987-982

4. Mulak A., Smereka A., Paradowski L.: Nowości i modyfikacje w Kryteriach Rzymskich IV. Gastroenterologia Kliniczna 2016; 8 (2): 57-59

5. Lee Y-T, Hu L-Y, Shen C-C, Huang M-W, Tsai S-J, Yang AC, et al.: Risk of Psychiatric Disorders following Irritable Bowel Syndrome: A Nationwide Population-Based Cohort Study. PLoS ONE 2015; 10 (7): e0133283

6. Tosic-Golubovic S., Miljkovic S., Nagorni A., Lazarevic D., Nikolic G.: Irritable bowel syndrome, anxiety, depression and personality characteristics. Psychiatria Danubina 2010; 22 (3): 418-424

7. Katsanos AH, Giannopoulos S, Tsivgoulis G.: The brain-gut axis in the pathophysiology of irritable bowel syndrome. ImmunoGastroenterology 2012; 1 (1): 23-26

8. Mulak A., Tache Y., Laurache M.: Sex hormones in the modulation of irritable bowel syndrome. World journal of gastroenterology: WJG 2014; 20 (20): 2433-2448

9. Nehring P., Mrozikiewicz-Rakowska B., Krasnodębski P., Karnafel W.: Zespół jelita drażliwego - nowe spojrzenie na etiopatogenezę. Przegląd Gastroenterologiczny 2011; 6 (1): 17 22

10. Scott K.P., Antoine J.M., Midtvedt T., et al. Manipulating the gut microbiota to maintain health and treat disease, Microbial Ecology in Health \& Disease 2015; 26, 25877

11. Lee B.J., Bak Y.T.: Irritable bowel syndrome, gut microbiota and probiotics. Journal of Neurogastroenterology and Motility 2011; 17 (3): 252-266

12. Dudzińska E., Wpływ mikroflory jelitowej na rozwój zespołu jelita drażliwego. Medycyna Środowiskowa - Enviromental Medicine 2016; 19 (3): 70-76

13. Fond G. et al.: Anxiety and depression comorbidities in irritable bowel syndrome (IBS): a systematic review and meta-analysis. European Archives of Psychiatry and Clinical Neuroscience 2014; 264 (8): 651-660

14. Hayes P. A., Fraher M. H., Quigley E.M.M.: Irritable Bowel Syndrome: The Role of Food in Pathogenesis and Management. Gastroenterology \& Hepatology 2014; 10 (3): 164-174

15. Lee K.N., Lee O.Y.: Intestinal microbiota in pathophysiology and management of irritable bowel syndrome. World journal of gastroenterology: WJG 2014; 20(27): 8886-8897

16. Hughes P.A., Zola H., Penttila I.A., Blackshaw L.A., Andrews J.M., Krumbiegel D.: Immune activation in irritable bowel syndrome: can neuroimmune interactions explain symptoms? American Journal of Gastroenterology 2013; 108 (7): 1066-1074

17. Irwin M.R., Miller A.H.: Depressive disorders and immunity: 20 years of progress and discovery. Brain, Behavior, and Immunity 2007; 21 (4): 374-383
18. Rudzki L., Frank M., Szulc A., Gałęcka M., Szlachta P., Barwinek D.: Od jelit do depresji-rola zaburzeń ciągłości bariery jelitowej i następcza aktywacja układu immunologicznego w zapalnej hipotezie depresji. Neuropsychiatria i Neuropsychologia 2012; 7 (2): $76-84$

19. Carabotti M., Scirocco A., Maselli M.A., Severi C.: The gut-brain axis:interactions between enteric microbiota, central and enteric nervous systems. Annals of Gastroenterology 2015; 28 (2): 203-209

20. Jones M.P., Dilley J.B., Drossman D., Crowell M.D.: Brain-gut connections in functional GI disorders:anatomic and physiologic relationships. Neurogastroenterology and Motility 2006; 18 (2): 91-103

21. Tsigos C., Chrousos G.P.: Hypothalamic-pituitary-adrenal axis, neuroendocrine factors and stress. Journal of Psychosomatic Research 2002; 53 (4): 865-871

22. Schmidt F.M., Lichtblau N., Minkwitz J., Chittka T., Thormann J., Kirkby K.C., et al.: Cytokine levels in depressed and nondepressed subjects, and masking effects of obesity. Journal of psychiatric research 2014; 55: 29-34

23. Fukudo S., Kanazawa M., Kano M., Sagami Y., Endo Y., Utsumi A., Nomura T., Hongo M:. Exaggerated motility of the descending colon with repetitive distention of the sigmoid colon in patients with irritable bowel syndrome. Journal of Gastroenerology 2002; 37 (14): 145-150

24. Claes S.J.: Corticotropin-releasing hormone ( $\mathrm{CRH})$ in psychiatry: from stress to psychopathology. Annals of Medicine 2004; 36 (1): 50-61

25. Kennedy P.J., Cryan J.F., Quigley E.M.M., Dinan T.G., Clarke G.: A sustained hypothalamic-pituitary-adrenal axis response to acute psychosocial stress in irritable bowel syndrome. Psychological Medicine 2014; 44 (14): 3123-3134

26. Hauser G., Pletikosic S., Tkalcic M.: Cognitive behavioral approach to understanding irritable bowel syndrome. World Journal of Gastroenterology 2014; 20 (22): 6744-6758

27. Heitkemper M.M., Chang L.: Do fluctuations in ovarian hormones affect gastrointestinal symptoms in women with irritable bowel syndrome? Gender Medicine 2009; 6 (2): 152-167

28. Mulak A., Tache Y., Larauche M.: Sex hormones in the modulation of irritable bowel syndrome. World Journal of Gastroenterology 2014, 20 (22): 2433-2448

29. Rybaczyk L.A., Bashaw M.J., Pathak D.R., Moody S.M., Gilders R.M., Holzschu D.L.: An overlooked connection: serotonergic mediation of estrogen-related physiology and pathology. BMC Womens Health 2005; 5:12

30. Houghton L.A., Lea R., Jackson N., Whorwell P.J.: The menstrual cycle affects rectal sensitivity in patients with irritable bowel syndrome but not healthy volunteers. Gut 2002; 50 (4): 471-474

31. Kane SV, Sable K, Hanauer SB.: The menstrual cycle and its effect on inflammatory bowel disease and irritable bowel syndrome: a prevalence study. American Journal of Gastroenterology 1998; 93 (10): 1867-1872

32. Crowell MD, Dubin NH, Robinson JC, Cheskin LJ, Schuster MM Heller BR, Whitehead WE.: Functional bowel disorders in women with dysmenorrhea. American Journal of Gastroenterology 1994; 89 (11): 1973-1977

33. Berry A, Bindocci E, Alleva E: NGF, brain and behavioral plasticity. Neural Plasticity 2012; 2012:784040

34. Spiller R.C.: Postinfectious irritable bowel syndrome Gastroenterology 2003; 124 (6): 1662-1671

35. Coss-Adame E., Rao S.S.: Brain and gut interactions in irritable bowel syndrome: new paradigms and new understandings. Current gastroenterology reports 2014; 16 (4): 379 
36. Ellingson B.M., Mayer E., Harris R.J., Ashe-McNally C., Naliboff B.D., Labus J.S., Tillisch K.: Diffusion tensor imaging detects microstructural reorganization in the brain associated with chronic irritable bowel syndrome. Pain 2013; 154 (9): 15281541

37. Labus J.S., Dinov I.D., Jiang Z., Ashe-McNally C., Zamanyan A., Shi Y., Hong J.Y., et al.: Irritable bowel syndrome in female patients is associated with alterations in structural brain networks. Pain 2014, 155 (1): 137-149

38. Seminowicz DA, Labus JS, Bueller JA, Tillisch K, Naliboff BD, Bushnell MC, Mayer EA: Regional gray matter density changes in brains of patients with irritable bowel syndrome. Gastroenterology 2010; 139 (1):48-57

39. Craggs JG, Price DD, Robinson ME: Enhancing the placebo response: fMRI evidence of memory and semantic processing in placebo analgesia. J Pain 2014; 15 (4):435-446

40. Adam B., Liebregts T., Holtmann G.: Mechanisms of disease: genetic of functional gastrointestinal disorders - searching the genes that matter. Nature Clinical Practice Gastroenterology \& Hepatology 2007; 4 (2): 102-110

41. Saito YA, Zimmerman JM, Harmsen WS, De Andrade M, Locke GR, Petersen GM, Talley NJ.: Irritable bowel syndrome aggregates strongly in families: a family-based case-control study. Neurogastroenterology \& Motility 2008; 20 (7): 790-797

42. Bengston MB, Ronning T, Vatn MH, Harris JR.: Irritable bowel syndrome in twins: genes and environment. Gut 2006; 55 (12): 1754-1759

43. Surdea-Blaga T., Baban A., Dumitrascu D.L.:. Psychosocial determinants of irritable bowel syndrome. World Journal of Gastroenterology 2012; 18 (7): 616-626

44. Hotoleanu C., Popp R., Trifa A.P., Nedelcu L., Dumitrascu D.L.: Genetic determination of irritable bowel syndrome. World Journal of Gastroenterology 2008; 14 (43): 6636-6640

45. Dunlop S.P., Coleman N.S., Blackshaw E. et al.: Abnormalities of 5-hydroxytryotamine metabolism in irritable bowel syndrome. Clinical Gastroenterology and Hepatology 2005; 3 (4): 349-357

46. Kapeller J., Houghton L.A., Mönnikes H., Walstab J, Möller D, Bönisch H, Burwinkel B., et al.: First evidence for an association of a functional variant in the microRNA-510 target site of the serotonin receptor-type $3 \mathrm{E}$ gene with diarrhea predominant irritable bowel syndrome. Human Molecular Genetics 2008; 17 (19): 2967-2977

47. Engel GL.: The need for a new medical model: a challenge for biomedicine. Science 1977; 196 (4286): 129-136

48. Lutgendorf SK, Costanzo ES.: Psychoneuroimmunology and health psychology: an integrative model. Brain, Behavior, and Immunity 2003; 17 (4): 225-232

49. Van Oudenhove L., Vandenberghe J., Demyttenaere K., Tack J.: Psychosocial factors, psychiatric illness and functional gastrointestinal disorders: a historical perspective. Digestion 2010; 82 (4): 201-210

50. Drossman D.A.: Do psychosocial factors define symptom severity and patient status in irritable bowel syndrome? American Journal of Medicine. 1990; 107 (5A): 41-50

51. Tilburg M.A.L., Palsson O.S., Whitehead W.E.: Which psychological factors exacerbate Irritable Bowel Syndrome? Development of a comprehensive model. Journal of psychosomatic research 2013; 74 (6):486-492

52. Whitehead W.E, Crowell M.D., Robinson J.C., et al.: Effects of Stressful Life Events on Bowel Symptoms - Subjects with Irritable - Bowel - Syndrome Compared with Subjects Without Bowel Dysfunction. Gut 1992; 33 (6): 825-830
53. Klooker T.K., Braak B., Painter R.C., et al.: Exposure to severe wartime conditions in early life is associated with an increased risk of irritable bowel syndrome: a population-based cohort study. American Journal of Gastroenterology 2009; 104 (9): 2250-2256

54. Hislop I.G.: Childhood deprivation: an antecedent of the irritable bowel syndrome. Medical Journal of Australia 1979; 1:372-374

55. Chang L.: The role of stress on physiologic responses and clinical symptoms in irritable bowel syndrome. Gastroenterology 2011; 140 (3): 761-765

56. Koloski NA, Talley NJ, Boyce PM.: A history of abuse in community subjects with irritable bowel syndrome and functional dyspepia: the role of other psychosocial variables. Digestion 2005; 72 (2-3): 86-96

57. Drossman D.A., Leserman J., Nachman G., Li Z.M., Gluck H., Toomey T.C., Mitchell C.M.: Sexual and physical abuse in women with functional or organic gastrointestinal disorders. Annals of Internal Medicine 1990; 113 (11): 828-833

58. Kanuri N., Cassell B., Bruce S.E., White K.S., Gott B.M., Gyawali C.P., Sayuk G.S.: The Impact of Abuse and Mood on Bowel Symptoms and Health-Related Quality of Life in Irritable Bowel Syndrome (IBS). Neurogastroenterology \& Motility 2016; 28(10): 1508-1517

59. Drossman D.A.: Abuse, trauma, and GI illness: is there a link? American Journal of Gastroenterology 2011; 106 (1): 14-25

60. Farnam A., Somi M.H., Sarami F., Farhang S.: Five personality dimensions in patients with irritable bowel syndrome. Neuropsychiatric Disease and Treatment 2008; 4 (5): 959-962

61. Drossman D.A., Leserman J., Li Z., Keefe F., Hu Y.J., Toomey TC.: Effects of coping on health outcome among women with gastrointestinal disorders. Psychosomatic Medicine 2000; 62 (3): 309-317

62. Chey W.D., Kurlander J., Eswaran S.: Irritable Bowel Syndrome A Clinical Review. JAMA 2015; 313 (9): 949-958

63. Halland M., Talley N.J.: New treatments for IBS. Nature Reviews Gastroenterology and Hepatology 2013; 10 (1): 13-23

64. Nehring P., Mrozikiewicz-Rakowska B., Krasnodębski P., Karnafel W.: Zespół jelita drażliwego-nowe spojrzenie na etiopatogenezę. Przegląd Gastroenterologiczny 2011; 6 (1): 1722

65. Ford A.C., Talley N.J., Schoenfeld P.S., et al.: Efficacy of antidepressants and psychological therapies in irritable bowel syndrome: systematic review and meta-analysis. Gut 2009; 58 (3): 367-378

66. Li J., Zhu W., Liu W., et al. Rifaximin for irritable bowel syndrome: a meta-analysis of randomized placebo-controlled trials. Medicine (Baltimore). 2016;95 (4):e2534

67. Ford A.C., Quigley E.M.M., Lacy B.E., et al.: Effect of Antidepressants and Psychological Therapies, Including Hypnotherapy, In Irritable Bowel Syndrome: Systematic Review and Meta-Analysis. The American Journal of Gastroenterology 2014; 109 (9): 1350-1365

68. Morgan V., Pickens D., Gautam S., Kessler R., Mertz H:. Amitriptyline reduces rectal pain related activation of the anterior cingulate cortex in patients with irritable bowel syndrome. Gut 2005; 54 (5): 601-607

69. Nitsch K., Jabłoński M., Samochowiec J., Kurpisz J.: Zaburzenia pod postacią somatyczną: problematyczne zjawisko problematyczna diagnoza. Psychiatria 2015; 12(2): 77-84

70. Gajewski P., Szczeklik A.: Interna Szczeklika 2016; wyd. 7: 10051006 
71. Creed F.H., Tomenson B., Chew-Graham C., Macfarlane G.J., Davies I., Jackson J., Littlewood A., McBeth J.: Multiple somatic symptoms predict impaired health status in functional somatic syndromes. International Journal of Behavioral Medicine 2013; 20:194-205

72. Hillilä M.T., Siivola M.T., Färkkilä M.A.: Comorbidity and use of health-care services among irritable bowel syndrome sufferers. Scandinavian Journal of Gastroenterology 2007; 42 (7): 799-806

73. Mayou R., Kirmayer L.J, Simon G., Kroenke K., Sharpe M.: Somatoform disorders: time for a new approach in DSM-V. The American Journal of Psychiatry 2005; 162 (5): 847-855

74. Van Oudenhove L, Törnblom H, Störsrud S, Tack J, Simrén M.: Depression and Somatization Are Associated With Increased Postprandial Symptoms in Patients with Irritable Bowel Syndrome. Gastroenterology. 2016; 150(4): 866-74

75. Lipowski Z.J.: Somatization: the concept and its clinical application. The American Journal of Psychiatry 1988; 145 (11): 1358-1368

76. W: Bilikiewicz A., Pużyński S., Rybakowski J., Wciórka J. (red.), Siwiak-Kobayashi M.: Zaburzenia występujące pod postacią somatyczną (somatoformiczne). Psychiatria, t. 2. 2002: 503-509

77. Grzesiak M., et al.: The Lifetime Prevalence of Anxiety Disorders Among Patients with Irritable Bowel Syndrome. Advances in Clinical and Experimental Medicine 2014; 23 (6): 987-992

78. Fadgyas-Stanculete M. et al.: The relationship between irritable bowel syndrome and psychiatric disorders: from molecular changes to clinical manifestations. Journal of Molecular Psychiatry 2014; 2 (1): 4
79. Tosic-Golubovic S., Miljkovic S., Nagorni A., Lazarevic D., Nikolic G.: Irritable bowel syndrome, anxiety, depression and personality characteristics. Psychiatria Danubina 2010; 22 (3): 418-424

80. Fond G. et al.: Anxiety and depression comorbidities in irritable bowel syndrome (IBS): a systematic review and meta-analysis. European Archives of Psychiatry and Clinical Neuroscience 2014; 264 (8): 651-660

81. Yao-Tung Lee et al.: Risk of Psychiatric Disorders following Irritable Bowel Syndrome: A Nationwide Population-Based Cohort Study. PLoS One 2015; 10(7):e0133283

82. Hausteiner-Wiehle C., Henningsen P.: Irritable bowel syndrome: relations with functional, mental, and somatoform disorders. World Journal of Gastroenterology 2014; 20 (20): 6024-6030

\section{Corresponding author}

Ewelina Soroka

II Department of Psychiatry and Psychiatric Rehabilitation, Medical University of Lublin e-mail: dziwota.e@gmail.com

Otrzymano: 24.01.2019

Zrecenzowano: 27.02.2019, 15.05.2019

Przyjęto do druku: 24.05.2019 